\title{
Stock and indices of carbon management under different soil use systems
}

Estoque e índices de manejo de carbono sob diferentes sistemas de uso do solo

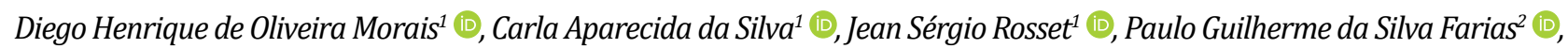

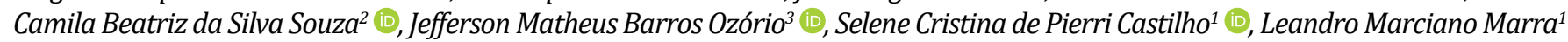

\section{A B S T R A C T}

The aim of this study was to evaluate the stock of total organic carbon (TOC) and to perform the physical-granulometric fractionation of soil organic matter (SOM) in different management systems (MS). Three MS and one reference area of Native Forest (NF) were studied, and the three systems were sugarcane (SC), permanent pasture (PP) and no-tillage system (NTS). Soil samples were collected in the $0-0.05,0.05-0.10,0.10-0.20-m$ layers. Soil density (Sd), TOC, stratification index $(\mathrm{SI})$, carbon stock (StockC), variation in StockC ( $\triangle$ StockC), carbon content of particulate organic matter (C-POM) and mineral organic matter (C-MOM), carbon stock index (CSI), lability (L), lability index (LI), and carbon management index (CMI) were determined. The MS presented higher Sd than the NF area. The NF area had higher TOC contents in the first layers, reaching $25.40 \mathrm{~g} \mathrm{~kg}^{-1}$ in the $0-0.05-\mathrm{m}$ layer, with the PP area having higher values than the NF in the $0.10-0.20-\mathrm{m}$ layer. The NF area showed the highest levels of C-POM (15.25 $\left.\mathrm{g} \mathrm{kg}^{-1}\right)$ and C-MOM $\left(10.15 \mathrm{~g} \mathrm{~kg}^{-1}\right)$ in the first layer. In the $0.10-0.20-\mathrm{m}$ layer, the PP and NTS systems were superior to the others. Regarding the C-MOM content, SC and PP showed higher levels in the 0.10-0.20-m layer. The highest CMI values were observed in the NTS and PP areas in the 0.10-0.20$\mathrm{m}$ layer. The MS increased the Sd and reduced the TOC levels. The different MS modified the POM fraction, and the MOM fraction was most impacted by the SC area. The lability of the SOM was altered by the MS in the most superficial layers.

Keywords: soil quality; labile carbon; environmental assessment.

\section{RE S U M 0}

O objetivo do presente trabalho foi avaliar os estoques de carbono orgânico total (COT) e realizar o fracionamento físico-granulométrico da matéria orgânica do solo (MOS) em diferentes sistemas de manejo (SM). Foram estudados três SM e uma área de referência de Mata Nativa (MN), sendo os três sistemas: cana-de-açúcar (CA); pastagem permanente (PP) e sistema plantio direto (SPD). Foram coletadas amostras de solos nas camadas $0-0,05,0,05-0,10$ e $0,10-0,20 \mathrm{~m}$. Foram determinados a densidade do solo (Ds), o COT, o índice de estratificação (IE), o estoque de carbono (EstC), a variação do EstC $(\triangle E s t C)$, os teores de carbono da matéria orgânica particulada (C-MOP) e mineral (C-MOM), o índice de estoque de carbono (IEC), a labilidade (L), o índice de labilidade (IL) e o índice de manejo de carbono (IMC). Os SM apresentaram Ds superior à área de $\mathrm{MN}$. $\mathrm{A}$ área de $\mathrm{MN}$ apresentou maiores teores de COT nas primeiras camadas, chegando a $25,40 \mathrm{~g} \mathrm{~kg}^{-1}$ na camada $0-0,05 \mathrm{~m}$, sendo a área de PP superior à $M N$ na camada de $0,10-0,20 \mathrm{~m}$. A área de MN apresentou os maiores teores de C-MOP $\left(15,25 \mathrm{~g} \mathrm{~kg}^{-1}\right)$ e C-MOM $\left(10,15 \mathrm{~g} \mathrm{~kg}^{-1}\right)$ na primeira camada. Para a camada de $0,10-0,20 \mathrm{~m}$, os sistemas de PP e SPD foram superiores aos demais. Para os teores de C-MOM, a CA e PP apresentaram maiores teores na camada 0,10-0,20 $\mathrm{m}$. Os maiores valores de IMC foram observados nas áreas de SPD e PP na camada de $0,10-0,20 \mathrm{~m}$. Os SM aumentaram a Ds e reduziram os teores de COT. Os diferentes SM modificaram a fração MOP, sendo a fração MOM mais impactada pela área de CA. A labilidade da MOS foi alterada pelos SM nas camadas mais superficiais.

Palavras-chave: qualidade do solo; carbono lábil; avaliação ambiental.

\footnotetext{
${ }^{1}$ Universidade Estadual de Mato Grosso do Sul - Mundo Novo (MS), Brazil.

2Universidade Estadual de Mato Grosso do Sul - Aquidauana (MS), Brazil.

${ }^{3}$ Universidade Estadual de Mato Grosso do Sul - Dourados (MS), Brazil.

Correspondence address: Jefferson Matheus Barros Ozório - BR 163, km 20 - Bairro Universitário - CEP: 79980-000 - Mundo Novo (MS), Brazil. E-mail: ozorio.jmb@outlook.com

Conflicts of interest: the authors declare that there are no conflicts of interest.

Funding: Fundação de Apoio ao Desenvolvimento do Ensino, Ciência e Tecnologia do Estado de Mato Grosso do Sul (Fundect) - Edital Fundect/ UEMS No. 25/2015.
}

Received on: 07/21/2020. Accepted on: 09/15/2020.

https://doi.org/10.5327/Z21769478867

This is an open access article distributed under the terms of the Creative Commons license. 


\section{Introduction}

The conversion of natural areas into production systems can, in addition to modifying the landscape, change the edaphic quality when not properly handled (Freitas et al., 2018). The different uses and managements directly influence soil attributes, such as carbon (C) (Lal, 2018; Ozório et al., 2019), besides causing changes in physical (Sales et al., 2018; Falcão et al., 2020), chemical (Souza et al., 2018; Assunção et al., 2019), and biological attributes of the soil (Borges et al., 2015; Barbosa et al., 2018).

Among the many attributes analyzed to evaluate the effects of the management systems and soil quality (SQ), soil organic matter (SOM) stands out (Nanzer et al., 2019; Lavallee et al., 2020; Poffenbarger et al., 2020). Thus, one of the methods for evaluating SQ is the analysis of C compartments of the physical fractions of the SOM (Cambardella and Elliott, 1992). Those are divided into two fractions, the particulate organic matter (POM), a fraction with high potential to indicate SQ in a short period of time (Bayer et al., 2002; Bongiorno et al., 2019); and the mineral organic matter (MOM), which is the most stable fraction of the SOM, being less sensitive to changes in a short period of time (Cambardella and Elliott, 1992).

With the data of physical fractionation, it is possible to obtain the carbon management index (CMI), developed by Blair et al. (1995), which is a useful tool to analyze the effects of different management systems, as it analyzes the effects of the systems on the quality and quantity of SOM in the same index (Ghosh et al., 2019).

The implementation of conservation production systems, such as well-managed pastures and the no-tillage system, can maintain or even increase soil carbon stocks (Salton et al., 2008; Rosset et al., 2019; Falcão et al., 2020), maintaining productive capacity and mitigating the emission of $\mathrm{C}$ dioxide $\left(\mathrm{CO}_{2}\right)$ into the atmosphere (Borges et al., 2015; Besen et al., 2018). In conventional soil tillage systems, the yearly plowing hinders the formation of stable soil aggregates, with consequent damage to the storage of C (Salton et al., 2008), as reported in studies analyzing soil quality in systems with sugarcane cultivation (Bordonal et al., 2018; Gomes et al., 2019).

Thus, the evaluation of SQ by quantifying the total organic carbon (TOC) contents and their respective fractions in areas with a known history of cultivation can produce accurate and conclusive results on the edaphic quality of the area. Therefore, the present study aimed to evaluate soil TOC contents and stocks, and the physical fractions of SOM in different management systems.

\section{Materials and Methods}

Soil collections were carried out at Vezozzo Farm, located in the municipality of Eldorado (Figure 1), Southern Cone region of the state of Mato Grosso do Sul, Brazil. The climate of the region is subtropical (Cfa), according to Köppen's classification and native vegetation of Atlantic Forest - Semideciduous Seasonal Forest (SEMADE, 2015), with soils classified as Argissolo Vermelho Amarelo distrofico típico
(Santos et al., 2018), equivalent Acrisols (IUSS WORKING GROUP WRB, 2015) and Ultisols (SOIL SURVEY STAFF, 2014), of sandy texture (Santos et al., 2018).

Four different areas were evaluated, three management systems in addition to a reference area of native forest, namely: sugarcane crop area (SC) - with 350 hectares, cultivated with sugarcane since 2006; permanent pasture area (PP) -implanted in 2003, with 2.5 hectares, with Brachiaria brizantha species subjected to grazing pressure by goats, with approximately $12 \mathrm{AU}^{\mathrm{A}}{ }^{-1}$; no-tillage system area (NTS) 240 hectares, where a succession of corn/soybean and cassava has been cultivated since 2002; and a native forest area (NF) of legal reserve with 160 hectares.

Disturbed and undisturbed soil samples were collected in the $0-0.05,0.05-0.10$ and $0.10-0.20$-m layers, with four replicates per management system and layer. Each composite sample of deformed soil was represented by ten simple samples within the four evaluated areas. In the NTS and SC, collection was carried out between the cultivation rows. In the areas of PP and NF, samples were randomly collected. The undisturbed samples for soil density analysis (Sd) were collected with the aid of a volumetric ring with a volume of $48.86 \mathrm{~cm}^{3}$, with four replicates in the areas and layers. In order to characterize the study areas, soil samples from the $0-0.20$-m layer were collected and then sent to the laboratory for chemical and physical characterization (Table 1).

Sd analyses were performed according to Claessen (1997), using the volumetric ring method. TOC was determined according to the methodology adapted from Yeomans and Bremner (1988). Based on the TOC results, the total organic carbon stocks (StockC) were calculated according to the equivalent mass method (Ellert and Bettany, 1995; Sisti et al., 2004).

To assess trends of accumulation or loss of TOC in relation to the NF (reference system of the original soil condition in this study), the variation in the StockC $(\Delta$ StockC) was calculated by the difference between the mean values of StockC of the NF and each of the management systems. The obtained value was divided by the thickness $(\mathrm{cm})$ of each layer and in the profile of $0-0.20 \mathrm{~m}$. With the results of the TOC contents, the carbon stratification index (SI) (Franzluebbers, 2002) was calculated using the relation between the TOC contents of the 0-0.05$\mathrm{m}$ and the 0.10-0.20-m layers.

The physical-granulometric fractionation of the SOM was performed according to the methodology of Cambardella and Elliott (1992), in which $20 \mathrm{~g}$ of air-dried fine earth (ADFE), together with $60 \mathrm{~mL}$ of sodium hexametaphosphate $\left(5 \mathrm{~g} \mathrm{~L}^{-1}\right)$ were placed in Erlenmeyer flasks of $250 \mathrm{~mL}$, being stirred for 16 hours in stirring table at a speed of $150 \mathrm{rpm}$. After the stirring period, samples were washed in a $53-\mu \mathrm{m}$ sieve, and the material retained in the sieve comprised the POM. Subsequently, the carbon content of particulate organic matter (C-POM) was obtained by the methodology of Yeomans and Bremner (1988), and the carbon content of mineral organic matter (C-MOM) was obtained from the differ- 
ence between TOC and C-POM. For the calculations of carbon stock of particulate organic matter (StockC-POM) and carbon stock of mineral organic matter (StockC-MOM), the methodology of the equivalent mass was used (Ellert and Bettany, 1995; Sisti et al., 2004).
After the determination of $\mathrm{C}$ fractions, the following indices were calculated to evaluate the quality of the SOM: carbon stock index (CSI), lability of SOM (L), lability index (LI), and carbon management index (CMI), according to Blair et al. (1995).
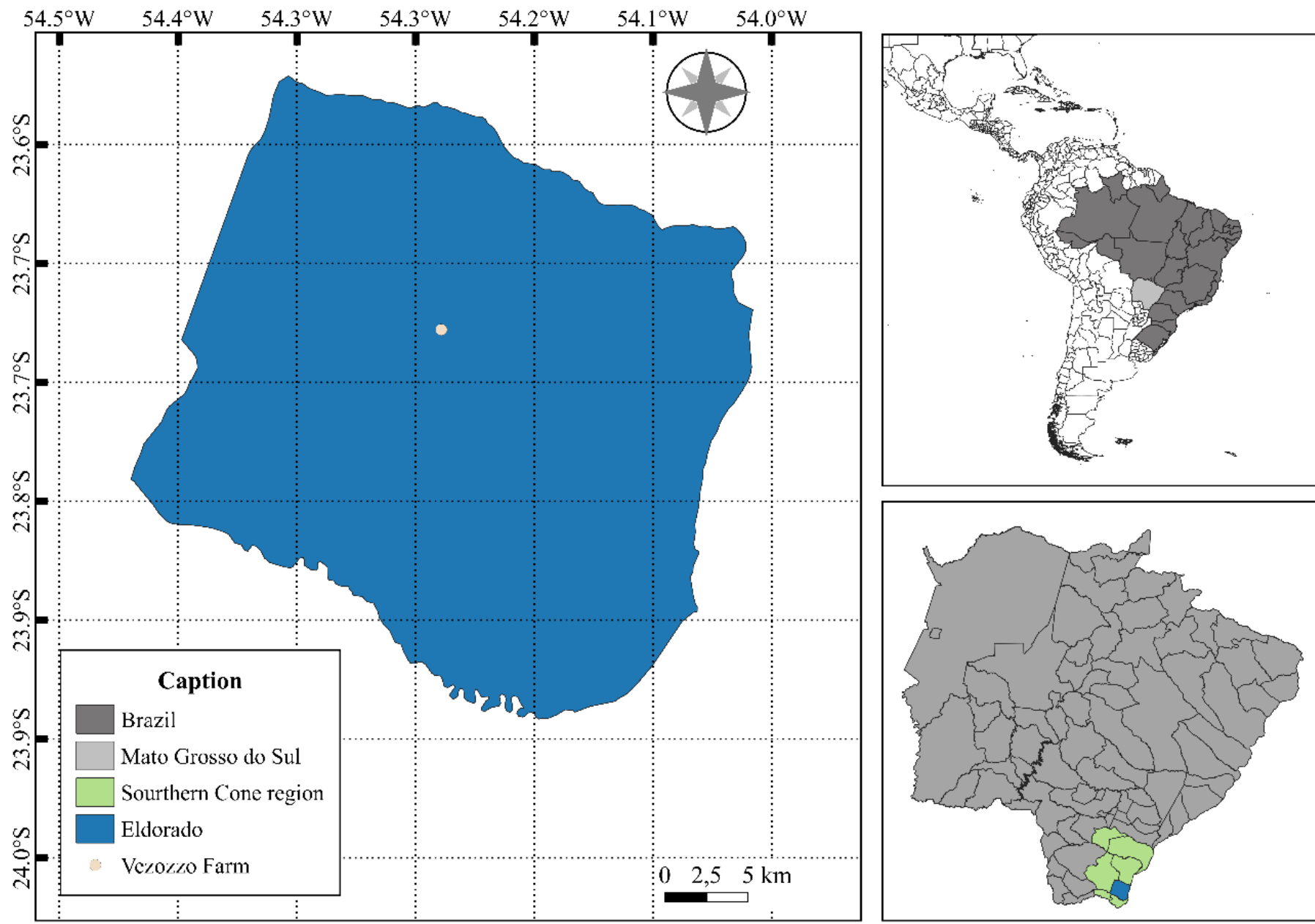

Figure 1 - Location of the municipality of Eldorado, state of Mato Grosso do Sul (MS), indicating the location of Vezozzo Farm, where the study collections were carried out. Cartography software: QGIS 3.12 Bucuresti.

Table 1 - Physical and chemical characterization of the soil (0-0.20-m layer) in the study areas.

\begin{tabular}{|c|c|c|c|c|c|c|c|c|c|c|c|c|c|c|}
\hline \multirow{2}{*}{ SA } & Sand & Silt & Clay & \multirow{2}{*}{$\frac{\mathrm{pH}}{\mathrm{CaCl}_{2}}$} & \multirow{2}{*}{$\frac{\mathrm{OM}}{\mathrm{g} \mathrm{dm^{-3 }}}$} & \multirow{2}{*}{$\frac{P}{\mathrm{mgdm}}$} & $\mathbf{K}$ & $\mathrm{Ca}$ & $\mathbf{M g}$ & Al & $\mathrm{H}+\mathrm{Al}$ & SB & CEC & \multirow{2}{*}{$\frac{\mathrm{V}}{\%}$} \\
\hline & \multicolumn{3}{|c|}{--.----g kg-1_------ } & & & & & 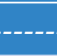 & 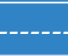 & $\operatorname{mol}_{c}$ & 3-..- & . & & \\
\hline SC & 779 & 100 & 121 & 5.13 & 10.11 & 3.52 & 0.20 & 2.1 & 1.1 & 0.02 & 1.4 & 3.40 & 4.80 & 70.8 \\
\hline NTS & 815 & 83 & 102 & 4.53 & 16.94 & 35.58 & 0.14 & 0.8 & 0.5 & 0.13 & 1.8 & 1.44 & 3.24 & 44.4 \\
\hline NF & 831 & 50 & 119 & 4.16 & 14.76 & 3.03 & 0.03 & 0.5 & 0.3 & 0.49 & 2.8 & 0.87 & 3.67 & 23.7 \\
\hline
\end{tabular}

SA: Study area; SC: sugarcane crop area; PP: permanent pasture; NTS: no-tillage system; NF: native forest. Physical characterization - Granulometry: pipette method. Chemical characterization - Calcium Chloride $(\mathrm{pH})$; Mehlich ( $\mathrm{P}$ and $\mathrm{K}) ; \mathrm{KCl} 1 \mathrm{~N}(\mathrm{Ca}, \mathrm{Mg}$ and $\mathrm{Al})$; Calcium Acetate pH 7 ( $\mathrm{H}$ + Al); OM: Organic matter; CEC: Cationic exchange capacity; V: Base Saturation; SB: Sum of bases. 
The results were subjected to variance analysis with F-test application, and the mean values were compared with each other by the Tukey test at 5\% probability with the aid of the GENES software (Cruz, 2006).

\section{Results and Discussion}

Regarding the Sd, it can be observed that the three managed areas had higher values than the area of NF in the 0-0.05-m layer, being similar to each other, ranging from 1.35 to $1.52 \mathrm{Mg} \mathrm{m}^{-3}$, whereas the area of NF presented a value of $1.08 \mathrm{Mg} \mathrm{m}^{-3}$ (Table 2). In the $0.05-0.10-\mathrm{m}$ layer, the highest Sd values were observed in the SC and PP areas, with values of 1.63 and $1.74 \mathrm{Mg} \mathrm{m}^{-3}$, respectively. In this same layer, the area of NTS $\left(1.35 \mathrm{Mg} \mathrm{m}^{-3}\right)$ and NF $\left(1.20 \mathrm{Mg} \mathrm{m}^{-3}\right)$ were similar to each other. In the 0.10-0.20-m layer, the areas of SC and PP had the highest values of Sd, and the area of NTS was similar to the NF (Table 2).

The highest values of Sd in the areas of SC and NTS are associated with the use of agricultural machinery during crop management procedures, which increase the pressure under the soil surface, promoting soil compaction (Sales et al., 2018). Awe et al. (2020), studying changes

Table 2 - Soil density (Sd), total organic carbon (TOC), and carbon stock (StockC) in the different management systems in the municipality of Eldorado, MS.

\begin{tabular}{|c|c|c|c|}
\hline \multirow{3}{*}{ MS } & Sd & TOC & StockC \\
\hline & $\mathrm{Mg} \mathrm{m}^{-3}$ & $\mathrm{~g} \mathrm{~kg}^{-1}$ & $\mathrm{Mg} \mathrm{ha}^{-1}$ \\
\hline & \multicolumn{3}{|c|}{$0-0.05 \mathrm{~m}$} \\
\hline SC & $1.52 \mathrm{a}$ & $12.68 \mathrm{c}$ & $6.84 \mathrm{~b}$ \\
\hline PP & $1.50 \mathrm{a}$ & $15.79 \mathrm{~b}$ & $8.53 \mathrm{ab}$ \\
\hline NTS & $1.35 \mathrm{a}$ & $15.01 \mathrm{~b}$ & $8.05 \mathrm{ab}$ \\
\hline NF & $1.08 \mathrm{~b}$ & $25.40 \mathrm{a}$ & $10.18 \mathrm{a}$ \\
\hline \multirow[t]{2}{*}{ CV (\%) } & 9.0 & 4.8 & 15.1 \\
\hline & \multicolumn{3}{|c|}{$0.05-0.10 \mathrm{~m}$} \\
\hline SC & $1.63 a$ & $11.63 c$ & $7.00 \mathrm{a}$ \\
\hline PP & $1.74 \mathrm{a}$ & $13.71 \mathrm{~b}$ & $8.25 \mathrm{a}$ \\
\hline NTS & $1.35 \mathrm{~b}$ & $12.57 \mathrm{bc}$ & $7.56 a$ \\
\hline NF & $1.20 \mathrm{~b}$ & $16.60 \mathrm{a}$ & $7.63 a$ \\
\hline \multirow[t]{2}{*}{ CV (\%) } & 5.2 & 5.5 & 8.4 \\
\hline & \multicolumn{3}{|c|}{$0.10-0.20 \mathrm{~m}$} \\
\hline SC & $1.62 \mathrm{a}$ & $9.21 \mathrm{~b}$ & $11.42 \mathrm{bc}$ \\
\hline PP & $1.70 \mathrm{a}$ & $13.00 \mathrm{a}$ & $16.11 \mathrm{a}$ \\
\hline NTS & $1.49 \mathrm{ab}$ & $11.13 \mathrm{ab}$ & $13.82 \mathrm{ab}$ \\
\hline NF & $1.24 \mathrm{~b}$ & $9.72 b$ & $10.46 c$ \\
\hline CV (\%) & 7.9 & 8.8 & 9.3 \\
\hline
\end{tabular}

MS: management systems; SC: sugarcane; PP: permanent pasture; NTS: no-tillage system; NF: native forest; CV (\%): coefficient of variation. Means followed by equal letters in the column, in each layer, do not differ from each other according to the Tukey test $(\mathrm{p} \leq 0.05)$. in soil physical attributes in sugarcane areas, reported an increase in Sd up to the 0.40 - $\mathrm{m}$ layer, due to machine traffic and soil revolving, corroborating the results of Rosset et al. (2014b) in sugarcane crop areas in the state of Mato Grosso do Sul. The highest values of Sd presented by the PP area are due to the absence of pasture maintenance, which favors degradation processes, such as surface disaggregation and particle rearrangement, thus increasing the Sd (Falcão et al., 2020). Vasques et al. (2019) in a pasture management study in Brazil, concluded that inadequate pasture management results in direct impacts on soil physical attributes, directly on Sd and soil porosity, which are extremely important in soil water regulation.

In the area of NF, the lowest values of Sd are associated with the intense litter deposition in these areas - which, together with the fact that there is no revolving, favors the activity of organisms (Borges et al., 2015), especially the edaphic macrofauna, that directly contribute to the decrease in Sd through their movement of the soil profile (Menandro et al., 2019; Velasquez and Lavelle, 2019). In all evaluated areas and layers, Sd values did not exceed $1.75 \mathrm{Mg} \mathrm{m}^{-3}$, considered an impediment for root development of crops in this sandy soil condition (Reinert et al., 2008; Sales et al., 2016).

It is noteworthy that in the $0-0.05$ and $0.05-0.10$-m layers, the TOC contents of the managed areas are lower than the NF. In the 0.05-0.10$\mathrm{m}$ layer, the SC, PP, and NTS presented contents of 11.63, 13.71, and $12.57 \mathrm{~g} \mathrm{~kg}^{-1}$, respectively. These higher contents in the NF area are due to the higher litter deposition of different forest extracts (Ozório et al., 2019), which increases the TOC contents in the most superficial layers of the soil (Assunção et al., 2019). Several authors have reported higher TOC contents in higher native areas compared with production systems in different regions of Brazil, soil types, and management systems (Borges et al., 2019; Maia et al., 2019; Santos et al., 2019; Ferreira et al., 2020; Medeiros et al., 2020).

Regarding the $0.10-0.20-\mathrm{m}$ layer, the highest levels of TOC were found in the PP area, with $13 \mathrm{~g} \mathrm{~kg}^{-1}$ (Table 2). These higher levels of TOC in more subsurface layers of areas cultivated with PP are explained because the root system of grasses deposits significant amounts of TOC in subsurface (Nanzer et al., 2019). Another explanation for the higher levels of TOC in the 0.10-0.20-m layer of PP, even with lower levels of TOC in surface layers, might be related to the process of pasture degradation by excessive grazing, with increased production of exudates in the roots, which increase the intake of $\mathrm{C}$ in more subsurface layers, as reported by Shen et al. (2020).

The highest StockC value in the $0-0.05$-m layer was observed in the $\mathrm{NF}$ area, with $10.18 \mathrm{Mg} \mathrm{ha}^{-1}$, being higher than the SC with $6.84 \mathrm{Mg} \mathrm{ha}^{-1}$. In the $0.05-0.10-\mathrm{m}$ layer, all the evaluated areas were similar to each other, ranging from 7.00 to $8.25 \mathrm{Mg} \mathrm{ha}^{-1}$. In the $0.10-0.20$-m layer, the highest values of StockC were observed in the areas of PP (16.11 $\left.\mathrm{Mg} \mathrm{ha}^{-1}\right)$ and NTS (13.82 $\mathrm{Mg} \mathrm{ha}^{-1}$ ), being higher than the area of NF (Table 2).

These results show that the management adopted in NTS and PP have contributed to the maintenance of the StockC both in surface and 
subsurface soil layers, a behavior previously observed by other authors (Rosset 2014a; 2014b; Rosset et al., 2016; Sales et al., 2018; Assunção et al., 2019; Rosset et al., 2019). This increase in soil StockC in the PP and NTS areas is important for improving soil quality, considering that $\mathrm{C}$ directly acts in the reduction of Sd (Velasquez and Lavelle, 2019; Falcão et al., 2020), porosity maintenance (Bertollo and Levien, 2019) as well as in the regulation of water infiltration (Silva et al., 2019), improving microorganism activity (Souza et al., 2018) and providing greater soil aggregation (Ozório et al., 2019; Udom and Omovbude, 2019).

The results of the TOC stratification index (SI) assessed in all studied areas, presented values above 1 (Figure 2). The managed areas did not present differences between them, with values ranging from 1.22 to 1.38 , which were different from the NF area, which presented an SI value of 2.63 .

According to Franzluebbers (2002) and Sá and Lal (2009), SI values greater than 1 indicate a high stratification ratio of soil C, which contributes to storing $\mathrm{C}$ in more subsurface soil layers. The highest SI value in the NF area is due to the constant entry of SOM into the soil surface, which causes the TOC content of the first layer to be higher in relation to deeper layers, as observed in Table 2. Salton et al. (2014) found SI of 1.70 for NF area in the Cerrado. Rosset et al. (2014a) reported a value of 3.43 SI in an Atlantic Forest area in western Paraná, Brazil.

Regarding the variation in carbon stock $(\Delta$ StockC), all managed areas showed negative variation, especially in the $0-0.05-\mathrm{m}$ layer (Figure 3). This negative variation in StockC in the $0-0.05$ - $\mathrm{m}$ layer is more evident in the SC area. This is mainly due to the intense soil management in the SC area, where gradation is used for crop renewal (Lopes et al., 2017). This process breaks the soil aggregates, leaving the SOM exposed to microorganisms that consume this organic matter, releasing $\mathrm{CO}_{2}$ (Bertollo and Levien, 2019; Gonçalves et al., 2019). This fact

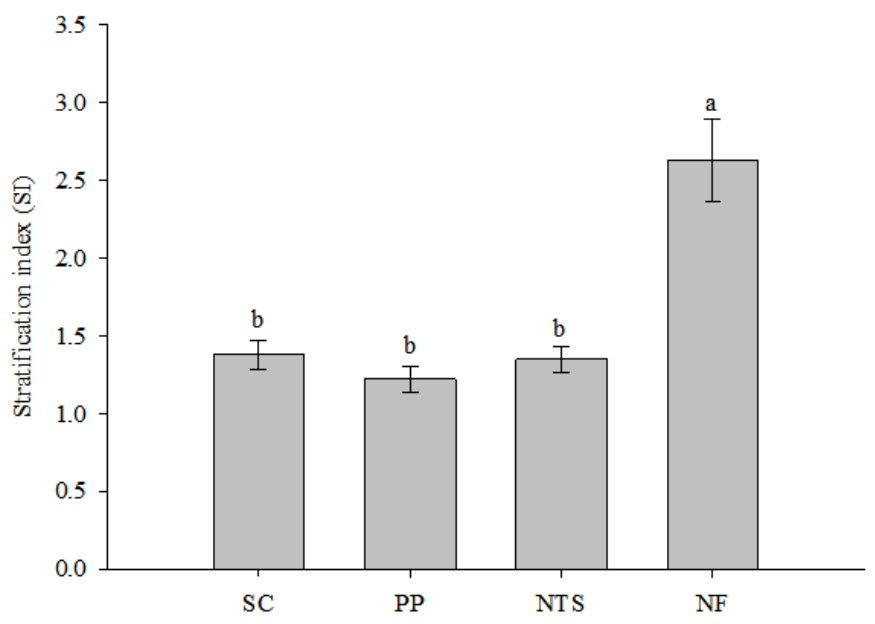

Figure 2 - Stratification index (SI) of total organic carbon as a function of different management systems in the municipality of Eldorado, MS. SC: sugarcane crop area; PP: permanent pasture; NTS: no-tillage system; NF: native forest. was also observed by Rosset et al. (2014b) in areas with different forms of sugarcane cultivation in the municipality of Maracajú, MS, Brazil.

In the PP area, especially in the $0.10-0.20$-m layer, but also in the $0-0.2-\mathrm{m}$ profile, the positive variation in the StockC was higher than the other managed areas. Nanzer et al. (2019) found higher StockC in a Brachiaria brizantha PP area, mainly due to the continuous renewal of the root system. Shen et al. (2020) highlights the importance and contribution of pastures to increase the StockC in deeper soil layers, even in pastures that show signs of degradation.

Considering the $\Delta$ StockC in the three stratified layers evaluated together (profile of $0-0.2 \mathrm{~m}$ ), it is possible to observe negative variation in the StockC only in the area of sugarcane cultivation (Figure 2). Some authors studying the effect of sugarcane production on soil $\mathrm{C}$ also observed StockC reduction in the layer of $0-0.2 \mathrm{~m}$ in SC areas in Brazil (Rosset et al., 2014b; Oliveira et al., 2016; Borges et al., 2019).

In the 0-0.05-m layer, the highest C-POM contents were observed in the NF area with $15.25 \mathrm{~g} \mathrm{~kg}^{-1}$, and the lowest content was observed in the SC area $\left(4.93 \mathrm{~g} \mathrm{~kg}^{-1}\right)$, whereas the PP and NTS areas presented intermediate levels. This same pattern was observed in the $0.05-0.10-\mathrm{m}$ layer, where the SC area presented $43.68 \%$ of the C-POM content compared with the reference area (Table 3). Gomes et al. (2019), in a study in southeastern Brazil, concluded that areas of SC are prone to losses of C-POM, both by soil revolving during crop renewal, and by losses in erosive processes that occur between the rows of these areas.

In the NF area, the highest levels of C-POM are attributed to the continuous deposition of soil litter (Gazolla et al., 2015; Rosset et al., 2019), with different plant extracts and different carbon-to-nitrogen $(\mathrm{C} / \mathrm{N})$ ratios between them (Ozório et al., 2019). The C-POM is extremely important for soil quality due to the strong relationship with the formation of soil macroaggregates (Tisdall and Oades, 1982; Six et al., 2000).

Regarding the C-MOM in the $0-0.05-\mathrm{m}$ layer, the highest content was observed in the NF area, $10.15 \mathrm{~g} \mathrm{~kg}^{-1}$, and the areas of SC, PP and NTS were similar to each other, with contents from $6.75 \mathrm{~g} \mathrm{~kg}^{-1}$ to 7.75 $\mathrm{g} \mathrm{kg}^{-1}$, respectively (Table 3). The absence of soil disturbance in the NF area favors the humification of SOM in the most superficial layer of the soil (Rosset et al., 2019). Similar results were found by Bueno et al. (2017), according to which a secondary forest area presented C-MOM values higher than managed areas, in the $0-0.10$-m layer, and by Rosset et al. (2019) in Atlantic Forest vegetation.

In the deepest layer evaluated (of $0.10-0.20 \mathrm{~m}$ ), there is an increase in the C-MOM content in the PP area (Table 3). This increase corroborates the pattern of increase in the TOC content of this area (Table 2). The increase in TOC content in subsurface layers and soil stability in PP areas favor the SOM humification process, becoming more recalcitrant (Rosset et al., 2019; Shen et al., 2020).

The representativeness of POM was higher in the most superficial layer of the soil, while the MOM percentage (\%MOM) increased according to increased depth in all areas (Table 3). The SC area presented 
lower POM percentage (\%POM) than the other areas, with $38.75 \%$, $35.14 \%$, and $31.80 \%$ in relation to TOC, in layers of $0-0.05 \mathrm{~m} ; 0.05-$ $0.10 \mathrm{~m}$; and $0.10-0.20 \mathrm{~m}$, respectively. On the other hand, the SC area presented \%MOM higher than $60 \%$ in all evaluated layers. This characterizes the absence of constant deposition of SOM (Bordonal et al., 2018), which hinders the balance between these two fractions of the SOM (Lal, 2018).

The areas of NF, PP, and NTS in all layers showed variations between $39 \%$ and $60 \%$ for $\% \mathrm{POM}$ and $\% \mathrm{MOM}$, respectively, and they were influenced by the evaluated layer (Table 3). Higher \%POM in surface soil layers is common due to the entry of organic matter de- posited on the soil surface (Cotrufo et al., 2019; Rosset et al., 2019; Lavallee et al., 2020).

The NF area had the highest value of StockPOM in the first layer evaluated, 6.12 $\mathrm{Mg} \mathrm{ha}^{-1}$, with PP and NTS areas having similar values, and the SC area had the lowest StockPOM, $2.68 \mathrm{Mg} \mathrm{ha}^{-1}$. In the 0.05-0.10-m layer, the areas of PP, NTS, and NF were similar to each other, ranging from $4.23 \mathrm{Mg} \mathrm{ha}^{-1}$ to $4.30 \mathrm{Mg} \mathrm{ha}^{-1}$, higher than the SC area. Finally, in the 0.10-0.20-m layer, the PP and NTS areas showed the highest StockPOM, 7.17 $\mathrm{Mg} \mathrm{ha}^{-1}$ and 7.22 $\mathrm{Mg} \mathrm{ha}^{-1}$, respectively (Table 3). C accumulation in the particulate fraction is important to keep the flow of biological activities in the soil (Batista et al., 2013), mainly

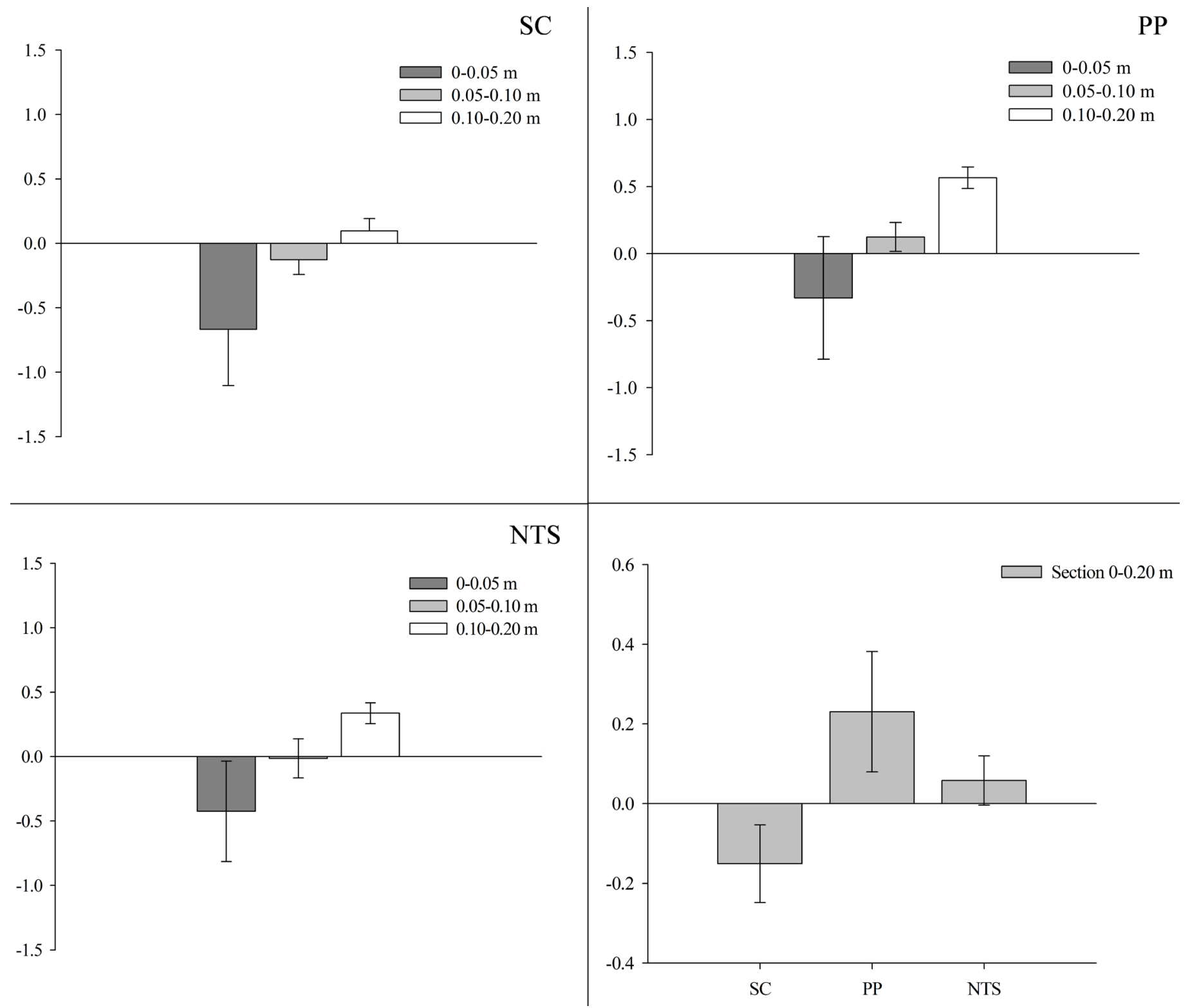

Figure 3 - Variation in TOC stock $(\triangle$ StockC) in the managed areas in the $0-0.05-\mathrm{m}, 0.05-0.10-\mathrm{m}$, and $0.10-0.20$ - $\mathrm{m}$ layers in relation to the native forest area, and in the $0-0.20$-m layer. 
by microorganisms that consume this SOM, turning it into more stable fractions (Borges et al., 2015; Rosset et al., 2019).

When observing the carbon stocks associated with minerals (StockMOM), in the first two layers evaluated, no difference was observed between the studied areas, ranging from $3.62 \mathrm{Mg} \mathrm{ha}^{-1}$ to $4.16 \mathrm{Mg} \mathrm{ha}^{-1}$ in the $0-0.05-\mathrm{m}$ layer, and from $3.32 \mathrm{Mg} \mathrm{ha}^{-1}$ to $4.53 \mathrm{Mg} \mathrm{ha}^{-1}$ in the $0.05-0.10$ $\mathrm{m}$ layer. In the 0.10-0.20-m layer, the highest values were observed in the SC and PP areas differing from the NF area (Table 3). This fraction presents advanced humification stage, being highly stable due to the interaction with the soil colloids and being located inside stable microaggregates (Assunção et al., 2019; Rosset et al., 2019; Ferreira et al., 2020).

The NF area had higher values of CSI for the first two layers studied (Table 3). This difference between the managed areas and the NF demonstrates the potential for $\mathrm{C}$ accumulation in the first layers of soil of areas under native vegetation (Ozório et al., 2019). When only assessing the managed areas, the NTS and PP areas differed from the SC area in the $0-0.05-\mathrm{m}$ layer. It is worth highlighting, mainly in the $0-0.05-\mathrm{m}$ layer, the low value of CSI (0.50) in the SC area, indicating that this area is not efficient in stocking $C$ (Bordonal et al., 2018). In the 0.10-0.20-m layer, the highest CSI was found in the PP area, being even higher than in the NF and SC areas (Table 3). The higher CSI in areas cultivated with $\mathrm{PP}$ are due to their volume of root system, which is efficient in the accumulation of C (Nanzer et al., 2019; Ozório et al., 2019; Shen et al., 2020).

In general, in all evaluated layers, the lability values $(\mathrm{L})$ of the SOM ranged from 0.47 to 1.50 . In the three layers evaluated, the SC area had values lower than 0.64 , different from the other managed areas, PP and NTS, and the NF area (Table 3). Regarding the LI, the same L pattern was found in the $0-0.05-\mathrm{m}$ and $0.05-0.10$-m layers, with the SC presenting the lowest values and the other treatments being similar to each other.

In this study, the $\mathrm{L}$ and LI values showed differences in $\mathrm{C}$ quality between the managed areas, especially comparing the SC area with the others (Table 3), demonstrating sensitivity in detecting changes in soil organic fraction of the evaluated areas. This assessment is essential to evaluate how different management systems alter soil attributes, thus allowing to develop strategies to minimize the negative impacts of agricultural production over the years of cultivation (Lal, 2018).

Table 3 - Carbon of particulate organic matter (C-POM), carbon of mineral organic matter (C-MOM), POM percentage (\%POM), MOM percentage (\%MOM), carbon stock of particulate organic matter (StockPOM), carbon stock of mineral organic matter (StockMOM), carbon stock index (CSI), lability of SOM (L), lability index (LI), and carbon management index (CMI) in the different management systems in the municipality of Eldorado, MS*.

\begin{tabular}{|c|c|c|c|c|c|c|c|c|c|c|}
\hline \multirow{3}{*}{ MS } & C-POM & C-MOM & POM & MOM & StockPOM & StockMOM & CSI & $\mathbf{L}$ & LI & CMI \\
\hline & \multicolumn{2}{|c|}{--------g kg-1'------- } & \multicolumn{2}{|c|}{-----\%"---- } & \multicolumn{2}{|c|}{------Mg ha'------- } & \multicolumn{4}{|c|}{ - ------------------------ } \\
\hline & \multicolumn{10}{|c|}{$0-0.05 \mathrm{~m}$} \\
\hline SC & $4.93 c$ & $7.75 b$ & $38.75 b$ & $61.25 \mathrm{a}$ & $2.68 c$ & $4.16 \mathrm{a}$ & $0.50 c$ & $0.64 \mathrm{~b}$ & $0.42 \mathrm{~b}$ & $21.30 \mathrm{c}$ \\
\hline PP & $8.54 b$ & $7.25 b$ & $54.44 \mathrm{a}$ & $45.56 b$ & $4.58 \mathrm{~b}$ & $3.94 \mathrm{a}$ & $0.62 b$ & $1.22 \mathrm{a}$ & $0.81 \mathrm{a}$ & $49.80 \mathrm{~b}$ \\
\hline NTS & $8.26 \mathrm{~b}$ & $6.75 b$ & $54.92 \mathrm{a}$ & $45.08 b$ & $4.42 b$ & $3.62 \mathrm{a}$ & $0.59 b$ & $1.22 \mathrm{a}$ & $0.82 \mathrm{a}$ & $48.37 \mathrm{~b}$ \\
\hline NF & $15.25 \mathrm{a}$ & $10.15 \mathrm{a}$ & $60.05 a$ & $39.95 b$ & $6.12 \mathrm{a}$ & $4.06 \mathrm{a}$ & $1.00 \mathrm{a}$ & $1.50 \mathrm{a}$ & $1.00 \mathrm{a}$ & $100.00 \mathrm{a}$ \\
\hline \multirow[t]{2}{*}{$\mathrm{CV}(\%)$} & 6.1 & 10.0 & 7.6 & 8.2 & 14.6 & 18.4 & 4.7 & 15.9 & 15.8 & 10.6 \\
\hline & \multicolumn{10}{|c|}{$0.05-0.10 \mathrm{~m}$} \\
\hline SC & $4.08 \mathrm{c}$ & $7.55 \mathrm{a}$ & $35.14 \mathrm{~b}$ & $64.86 a$ & $2.45 b$ & $4.53 \mathrm{a}$ & $0.70 c$ & $0.55 b$ & $0.42 b$ & $29.73 b$ \\
\hline $\mathrm{PP}$ & $7.30 \mathrm{~b}$ & $6.41 \mathrm{ab}$ & $53.66 \mathrm{a}$ & $46.34 \mathrm{a}$ & $4.38 \mathrm{a}$ & $3.86 \mathrm{a}$ & $0.83 b$ & $1.20 \mathrm{a}$ & $0.96 \mathrm{a}$ & $78.04 \mathrm{a}$ \\
\hline NTS & $7.05 \mathrm{~b}$ & $5.52 b$ & $56.25 \mathrm{a}$ & $43.75 b$ & $4.23 \mathrm{a}$ & $3.32 \mathrm{a}$ & $0.75 c$ & $1.30 \mathrm{a}$ & $1.03 \mathrm{a}$ & $77.46 \mathrm{a}$ \\
\hline $\mathrm{NF}$ & $9.34 \mathrm{a}$ & $7.26 \mathrm{ab}$ & $56.24 \mathrm{a}$ & $43.76 b$ & $4.30 \mathrm{a}$ & $3.32 \mathrm{a}$ & $1.00 \mathrm{a}$ & $1.29 \mathrm{a}$ & $1.00 \mathrm{a}$ & $100.00 \mathrm{a}$ \\
\hline \multirow[t]{2}{*}{ CV (\%) } & 7.2 & 14.2 & 10.5 & 10.6 & 9.6 & 16.0 & 4.0 & 23.7 & 29.9 & 24.6 \\
\hline & \multicolumn{10}{|c|}{$0.10-0.20 \mathrm{~m}$} \\
\hline SC & $2.92 \mathrm{c}$ & $6.29 \mathrm{ab}$ & $31.80 \mathrm{c}$ & $68.20 \mathrm{a}$ & $3.61 \mathrm{~b}$ & $7.80 \mathrm{ab}$ & $0.95 b$ & $0.47 \mathrm{c}$ & $0.59 c$ & $56.57 d$ \\
\hline $\mathrm{PP}$ & $5.79 \mathrm{a}$ & $7.21 \mathrm{a}$ & $44.61 \mathrm{~b}$ & $55.39 b$ & $7.17 \mathrm{a}$ & $8.93 \mathrm{a}$ & $1.34 \mathrm{a}$ & $0.81 b$ & $1.03 \mathrm{~b}$ & $137.39 \mathrm{~b}$ \\
\hline NTS & $5.82 \mathrm{a}$ & $5.31 \mathrm{~b}$ & $52.31 \mathrm{a}$ & $47.69 c$ & $7.22 \mathrm{a}$ & $6.59 b c$ & $1.15 \mathrm{ab}$ & $1.10 \mathrm{a}$ & $1.40 \mathrm{a}$ & $160.36 a$ \\
\hline $\mathrm{NF}$ & $4.26 \mathrm{~b}$ & $5.46 \mathrm{~b}$ & $44.00 \mathrm{~b}$ & $56.00 \mathrm{~b}$ & $4.59 \mathrm{~b}$ & $5.86 c$ & $1.00 \mathrm{~b}$ & $0.79 b$ & $1.00 \mathrm{~b}$ & $100.00 c$ \\
\hline CV (\%) & 8.5 & 10.7 & 4.6 & 3.5 & 8.9 & 11.2 & 8.9 & 6.8 & 7.3 & 8.1 \\
\hline
\end{tabular}

${ }^{\star}$ Means followed by equal letters in the column, in each layer, do not differ from each other according to the Tukey test (p $\leq 0.05$ ); CV: coefficient of variation. 
It was observed that in the $0-0.05-\mathrm{m}$ layer, the NF area presented higher $\mathrm{CMI}$ in relation to the managed areas, and the cultivation areas presented values between 21.30 and 49.80 in the $0-0.05$ - $\mathrm{m}$ layer, and 29.73 and 78.04 in the $0.05-0.10-m$ layer (Table 3 ). This shows the impact that the areas of SC, PP, and NTS caused on the quantity and quality of $\mathrm{C}$ in the most superficial layers of the soil, compared with the NF area. Similar results were observed by other authors in several study areas (Rosset et al., 2019; Lavallee et al., 2020; Poffenbarger et al., 2020).

Considering the CMI results in the 0.10-0.20-m layer, the PP and NTS areas exceed the reference value of the NF, which indicates that even compromising the quantity and quality of $\mathrm{C}$ on the surface, the systems have been contributing to the improvement of SOM in the most subsurface layer of the soil. This may benefit the edaphic quality in these areas, favoring other chemical, physical, and biological attributes of the soil (Lal, 2018; Assunção et al., 2019; Ozório et al., 2019; Rosset et al., 2019; Ferreira et al., 2020).

\section{Conclusions}

The managed areas modify the density, total organic carbon content, and soil carbon stock when compared with the reference area.

The particulate and mineral fractions of soil organic matter are altered in the different management systems, and the sugarcane area compromised the presence of particulate organic matter.

The managed areas, through the evaluation of the carbon management index, compromise organic matter in the most superficial layers.

\section{Acknowledgments}

The authors thank the farmers who made their areas available for the development of this study.

\section{Contribution of authors:}

Morais, D.H.O.: Conceptualization, Methodology, Validation, Formal analysis, Investigation, Resources, Data curation, Writing - original draft. Silva, C.A.: Conceptualization, Methodology, Validation, Formal analysis, Investigation, Resources, Writing — original draft. Rosset, J.S.: Conceptualization, Methodology, Validation, Formal analysis, Investigation, Visualization, Supervision, Project administration. Farias, P.G.S.: Methodology, Validation, Formal analysis, Investigation, Resources. Souza, C.B.S.: Formal analysis, Investigation, Resources, Data curation, Writing - review \& editing. Ozório, J.M.B.: Resources, Software, Project administration, Formal analysis, Funding. Castilho, S.C.P.: Methodology, Validation, Formal analysis, Investigation, Visualization. Marra, L.M.: Methodology, Validation, Formal analysis, Investigation, Supervision, Visualization.

\section{References}

Assunção, S.A.; Pereira, M.G.; Rosset, J.S.; Berbara, R.L.L.; García, A.C., 2019. Carbon input and the structural quality of soil organic matter as a function of agricultural management in a tropical climate region of Brazil. Science of the Total Environment, v. 658, 901-911. https://doi.org/10.1016/j. scitotenv.2018.12.271.

Awe, G.O.; Reichert, J.M.; Fontanela, E., 2020. Sugarcane production in the subtropics: Seasonal changes in soil properties and crop yield in no-tillage, inverting and minimum tillage. Soil and Tillage Research, v. 196, 104447. https://doi.org/10.1016/j.still.2019.104447.

Barbosa, E.A.A.; Matsura, E.E.; Santos, L.N.S.; Nazário, A.A.; Gonçalves, I.Z.; Feitosa, D.R.C., 2018. Soil attributes and quality under treated domestic sewage irrigation in sugarcane. Revista Brasileira de Engenharia Agrícola e Ambiental, v. 22, (2), 137-142. https://doi.org/10.1590/1807-1929/agriambi. v22n2p137-142.

Batista, I.; Pereira, M.G.; Correia, M.E.F.; Bieluczyk, W.; Schiavo, J.A.; Rows, J.R.C., 2013. Teores e estoque de carbono em frações lábeis e recalcitrantes da matéria orgânica do solo sob integração lavoura-pecuária no bioma Cerrado. Semina: Ciências Agrárias, v. 34, (6 Suppl. 1), 3377-3388. http://dx.doi. org/10.5433/1679-0359.2013v34n6Supl1p3377.

Bayer, C.; Mielniczuk, J.; Martin-Neto, L.; Ernani, P.R., 2002. Stocks and humification degree of organic matter fractions as afected by no-tillage on a subtropical soil. Plant and Soil, v. 238, (1), 133-140. https://doi. org/10.1023/A:1014284329618.
Bertollo, A.M.; Levien, R., 2019. Compactação do solo em Sistema de Plantio Direto na palha. Pesquisa Agropecuária Gaúcha, v. 25, (3), 208-218. https:// doi.org/10.36812/pag.2019253208-218.

Besen, R.M.; Ribeiro, R.H.; Monteiro, A.N.T.R.; Iwasaki, G.S.; Piva, J.T., 2018. Práticas conservacionistas do solo e emissão de gases do efeito estufa no Brasil. Scientia Agropecuaria, v. 9, (3), 429-439. http://dx.doi.org/10.17268/sci.agropecu.2018.03.15.

Blair, G.J.; Lefroy, B.; Lisle, L., 1995. Soil carbon fractions, based on their degree of oxidation, and the development of a carbon management index for agricultural systems. Australian Journal of Agricultural Research, v. 46, (7), 1459-1466. https://doi.org/10.1071/AR9951459.

Bongiorno, G.; Bünemann, E.K.; Oguejiofor, C.U.; Meier, J.; Gort, G.; Comans, R.; Mäder, P.; Brussaard, L.; Goede, R., 2019. Sensitivity of labile carbon fractions to tillage and organic matter management and their potential as comprehensive soil quality indicators across pedoclimatic conditions in Europe. Ecological Indicators, v. 99, 38-50. https://doi.org/10.1016/j.ecolind.2018.12.008.

Bordonal, R.O.; Menandro, L.M.S.; Barbosa, L.C.; Lal, R.; Milori, D.M.B.P.; Kolln, O.T.; Franco, H.C.J.; Carvalho, J.L.N., 2018. Sugarcane yield and soil carbon response to straw removal in south-central Brazil. Geoderma, v. 328, 79-90. https://doi.org/10.1016/j.geoderma.2018.05.003.

Borges, C.; Ribeiro, B.T.; Wendling, B.; Cabral, D.A., 2015. Agregação do solo, carbono orgânico e emissão de $\mathrm{CO}_{2}$ em áreas sob diferentes usos no Cerrado, região do Triângulo Mineiro. Revista Ambiente \& Água, v. 10, (3), 660-675. https://doi.org/10.4136/ambi-agua.1573. 
Borges, L.D.A.B.; Ramos, M.L.G.; Fernandes, P.M.; Carneiro, M.A.C.; Silva, A.M.M., 2019. Organic cultivation of sugarcane restores soil organic carbon and nitrogen. Organic Agriculture, v. 9, (4), 435-444. https://doi.org/10.1007/ s13165-018-0234-x.

Bueno, J.M.M.; Dalmolin, R.S.D.; Miguel, P., 2017. Frações do carbono orgânico do solo sob diferentes usos da terra em áreas de agricultura familiar. Revista Brasileira de Agroecologia, v. 12, (3), 194-201.

Cambardella, C.A.; Elliott, E.T., 1992. Particulate soil organic-matter changes across a grassland cultivation sequence. Soil Science Society of America Journal, v. 56, (3), 777-783. https://doi.org/10.2136/ sssaj1992.03615995005600030017x.

Claessen, M.E.C., 1997. Manual de métodos de análise de solo. 2. ed. Embrapa, Rio de Janeiro, $212 \mathrm{pp}$.

Cotrufo, M.F.; Ranalli, M.G.; Haddix, M.L.; Six, J.; Lugato, E., 2019. Soil carbon storage informed by particulate and mineral-associated organic matter. Nature Geoscience, v. 12, (12), 989-994. https://doi.org/10.1038/ s41561-019-0484-6.

Cruz, C.D., 2006. Programa genes: biometria. Editora da UFV, Viçosa, 382 pp.

Ellert, B.H.; Bettany, J.R., 1995. Calculation of organic matter and nutrients stored in soils under contrasting management regimes. Canadian Journal Soil Science, v. 75, (4), 529-538. https://doi.org/10.4141/cjss95-075.

Falcão, K.S.; Monteiro, F.N.; Ozório, J.M.B.; Souza, C.B.S.; Farias, P.G.S.; Menezes, R.S.; Panachuki, E.; Rosset, J.S., 2020. Estoque de carbono e agregação do solo sob diferentes sistemas de uso no Cerrado. Revista Brasileira de Ciências Ambientais (Online), v. 55, (2), 242-255. https://doi.org/10.5327/ Z2176-947820200695.

Ferreira, C.R.; Silva Neto, E.C.; Pereira, M.G.; Guedes, J.N.; Rosset, J.S.; Anjos, L.H.C., 2020. Dynamics of soil aggregation and organic carbon fractions over 23 years of no-till management. Soil \& Tillage Research, v. 198, 104533. https:// doi.org/10.1016/j.still.2019.104533.

Franzluebbers, A.J., 2002. Soil organic matter stratification ratio as an indicator of soil quality. Soil \& Tillage Research, v. 66, (2), 95-106. https://doi. org/10.1016/S0167-1987(02)00018-1.

Freitas, L.; Oliveira, I.A.; Casagrande, J.C.; Silva, L.S.; Campos, M.C.C., 2018. Estoque de carbono de Latossolos em sistemas de manejo natural e alterado. Ciência Florestal, v. 28, (1), 228-239. http://dx.doi. org/10.5902/1980509831575.

Gazolla, P.R.; Guareschi, R.F.; Perin, A.; Pereira, M.G.; Rossi, C.Q., 2015. Frações da matéria orgânica do solo sob pastagem, sistema plantio direto e integração lavoura-pecuária. Semina: Ciências Agrárias, v. 36, (2), 693-704. http://dx.doi.org/10.5433/1679-0359.2015v36n2p693.

Ghosh, B.N.; Meena, V.S.; Singh, R.J.; Alam, N.M.; Patra, S.; Bhattacharyya, R.; Sharma, N.K.; Dadhwal, K.S.; Mishra, P.K., 2019. Effects of fertilization on soil aggregation, carbon distribution and carbon management index of maizewheat rotation in the north-western Indian Himalayas. Ecological Indicators, v. 105, 415-424. https://doi.org/10.1016/j.ecolind.2018.02.050.

Gomes, T.F.; Van De Broek, M.; Govers, G.; Silva, R.W.; Moraes, J.M.; Camargo, P.B.; Mazzi, E.A.; Martinelli, L.A., 2019. Runoff, soil loss, and sources of particulate organic carbon delivered to streams by sugarcane and riparian areas: An isotopic approach. Catena, v. 181, 104083. https://doi.org/10.1016/j. catena.2019.104083.

Gonçalves, V.A.; Melo, C.A.D.; Assis, I.R.; Ferreira, L.R.; Saraiva, D.T., 2019. Biomassa e atividade microbiana de solo sob diferentes sistemas de plantio e sucessões de culturas. Revista de Ciências Agrárias, v. 62, 1-8. http://dx.doi. org/10.22491/rca.2019.2611.
IUSS Working Group WRB. 2015. World Reference Base for Soil Resources (WRB), sistema universal reconhecido pela International Union of Soil Science (IUSS) e FAO. Available from: <http://www.fao.org/3/a-i3794e.pdf $>$. Access on May 16, 2021.

Lal, R., 2018. Digging deeper: A holistic perspective of factors affecting soil organic carbon sequestration in agroecosystems. Global Change Biology, v. 24, (8), 3285-3301. https://doi.org/10.1111/gcb.14054.

Lavallee, J.M.; Soong, J.L.; Cotrufo, M.F., 2020. Conceptualizing soil organic matter into particulate and mineral-associated forms to address global change in the 21st century. Global Change Biology, v. 26, (1), 261-273. https://doi. org/10.1111/gcb.14859.

Lopes, I.M.; Assunção, S.A.; Oliveira, A.P.P.; Anjos, L.H.C.; Pereira, M.G.; Lima, E., 2017. Carbon fractions and soil fertility affected by tillage and sugarcane residue management an Xanthic Udult. Semina: Ciências Agrárias, v. 38, (5), 2921-2932. http://dx.doi.org/10.5433/1679-0359.2017v38n5p2921.

Maia, S.M.F.; Otutumi, A.T.; Mendonça, E.S.; Neves, J.C.L. Oliveira, T.S., 2019. Combined effect of intercropping and minimum tillage on soil carbon sequestration and organic matter pools in the semiarid region of Brazil. Soil Research, v. 57, (3), 266-275. https://doi.org/10.1071/SR17336

Medeiros, A.S.; Maia, S.M.F.; Santos, T.C.; Gomes, T.C.A., 2020. Soil carbon losses in conventional farming systems due to land-use change in the Brazilian semi-arid region. Agriculture, Ecosystems \& Environment, v. 287, 106690. https://doi.org/10.1016/j.agee.2019.106690.

Menandro, L.M.S.; Moraes, L.O.; Borges, C.D.; Cherubin, M.R.; Castioni, G.A.; Carvalho, J.L.N., 2019. Soil Macrofauna Responses to Sugarcane Straw Removal for Bioenergy Production. Bioenergy Research, v. 12, (4), 944-957. https://doi.org/10.1007/s12155-019-10053-2.

Nanzer, M.C.; Ensinas, S.C.; Barbosa, G.F.; Barreta, P.G.V.; Oliveira, T.P.; Silva, J.R.M.; Paulino, L.A., 2019. Estoque de carbono orgânico total e fracionamento granulométrico da matéria orgânica em sistemas de uso do solo no Cerrado. Revista de Ciências Agroveterinárias, v. 18, (1), 136-145. https://doi. org/10.5965/223811711812019136.

Oliveira, D.M.S.; Paustian, K.; Davies, C.A.; Cherubin, M.R.; Franco, A.L.C.; Cerri, C.C.; Cerri, C.E.P., 2016. Soil carbon changes in areas undergoing expansion of sugarcane into pastures in south-central Brazil. Agriculture, Ecosystems \& Environment, v. 228, 38-48. https://doi.org/10.1016/j. agee.2016.05.005.

Ozório, J.M.B.; Rosset, J.S.; Schiavo, J.; Panachuki, E.; Souza, C.B.S.; Menezes, R.S.; Ximenes, T.S.; Castilho, S.C.P.; Marra, L.M., 2019. Estoque de carbono e agregação do solo sob fragmentos florestais nos biomas Mata Atlântica e Cerrado. Revista Brasileira de Ciências Ambientais, (53), 97-116. https://doi. org/10.5327/Z2176-947820190518.

Poffenbarger, H.J.; Olk, D.C.; Cambardella, C.; Kersey, J.; Liebman, M.; Mallarino, A.; Six, J.; Castellano, M.J., 2020. Whole-profile soil organic matter content, composition, and stability under cropping systems that differ in belowground inputs. Agriculture, Ecosystems \& Environment, v. 291, 106810. https://doi.org/10.1016/j.agee.2019.106810.

Reinert, D.J.; Albuquerque, J.A.; Reichert, J.M.; Aita, C.; Andrada, M.M.C., 2008. Limites críticos de densidade do solo para o crescimento de raízes de plantas de cobertura em Argissolo Vermelho. Revista Brasileira de Ciência do Solo, v. 32, (5), 1805-1816. https://doi.org/10.1590/S0100-06832008000500002.

Rosset, J.S.; Lana, M.C.; Pereira, M.G.; Schiavo, J.A.; Rampim, L.; Sarto, M.V.M., 2016. Frações químicas e oxidáveis da matéria orgânica do solo sob diferentes sistemas de manejo, em Latossolo Vermelho. Pesquisa Agropecuária Brasileira, v. 51, (9), 1529-1538. https://doi.org/10.1590/s0100$204 \times 2016000900052$. 
Rosset, J.S.; Lana, M.C.; Pereira, M.G.; Schiavo, J.A.; Rampim, L.; Sarto, M.V.M., 2019. Organic matter and soil aggregation in agricultural systems with different adoption times. Semina: Ciências Agrárias, v. 40, (6 Suppl.), 34433460. http://dx.doi.org/10.5433/1679-0359.2019v40n6Supl3p3443.

Rosset, J.S.; Lana, M.C.; Pereira, M.G.; Schiavo, J.A.; Rampim, L.; Sarto, M.V.M.; Seidel, E.P., 2014a. Carbon stock, chemical and physical properties of soils under management systems with different deployment times in western region of Paraná, Brazil. Semina: Ciências Agrárias, v. 35, (6), 3053-3072. http://dx.doi.org/10.5433/1679-0359.2014v35n6p3053.

Rosset, J.S.; Schiavo, J.A.; Atanázio, R.A.R., 2014b. Atributos químicos, estoque de carbono orgânico total e das frações humificadas da matéria orgânica do solo em diferentes sistemas de manejo de cana-de-açúcar. Semina: Ciências Agrárias, v. 35, (5), 2351-2366. http://dx.doi.org/10.5433/16790359.2014v35n5p2351.

Sá, J.C.M.; Lal, R., 2009. Stratification ratio of soil organic matter pools as an indicator of carbon sequestration in a tillage chronosequence on a Brazilian Oxisol. Soil \& Tillage Research, v. 103, (1), 46-56. https://doi.org/10.1016/j. still.2008.09.003.

Sales, A.; Silva, A.R.; Veloso, C.A.C.; Carvalho, E.J.M.; Miranda, B.M., 2018. Carbono orgânico e atributos físicos do solo sob manejo agropecuário sustentável na Amazônia legal. Colloquium Agrariae, v. 14, (1), 1-15.

Sales, R.P.; Portugal, A.F.; Moreira, J.A.A.; Kondo, M.K.; Pegoraro, R.F., 2016. Qualidade física de um Latossolo sob plantio direto e preparo convencional no semiárido. Revista Ciência Agronômica, v. 47, (3), 429-438.

Salton, J.C.; Mercante, F.M.; Tomazi, M.; Zanatta, J.A.; Concenço, G.; Silva, W.M.; Retore, M., 2014. Integrated crop-livestock system in tropical Brazil: Toward a sustainable production system. Agriculture, Ecosystems \& Environment, v. 190, 70-79. https://doi.org/10.1016/j.agee.2013.09.023.

Salton, J.C.; Mielniczuk, J.; Bayer, C.; Boeni, M.; Conceição, P.C.; Fabrício, A.C.; Macedo, M.C.M.; Broch, D.L., 2008. Agregação e estabilidade de agregados do solo em sistemas agropecuários em Mato Grosso do Sul. Revista Brasileira de Ciência do Solo, v. 32, (1), 11-21. https://doi.org/10.1590/S010006832008000100002.

Santos, H.G.; Jacomine, P.K.T.; Anjos, L.H.C.; Oliveira, V.A.; Lumbreras, J.F.; Coelho, M.R.; Almeida, J.A.; Araújo Filho, J.C.; Oliveira, J.B.; Cunha, T.J.F., 2018. Sistema Brasileiro de Classificação de Solos. 5. ed. Embrapa, Brasília, 356 pp.

Santos, U.J.; Duda, G.P.; Marques, M.C.; Medeiros, E.V.; Lima, J.R.S.; Souza, E.S.; Brossard, M.; Hammecker, C., 2019. Soil organic carbon fractions and humic substances are affected by land uses of Caatinga forest in Brazil. Arid Land Research and Management, v. 33, (3), 255-273. https://doi.org/10.1080/1 5324982.2018.1555871.
Secretaria de Estado de Meio Ambiente e Desenvolvimento Econômico (SEMADE). 2015. Estudo da Dimensão Territorial do Estado de Mato Grosso do Sul: Regiões de Planejamento. Governo do Estado de Mato Grosso do Sul, Campo Grande, 91 pp.

Shen, X.; Yang, F.; Xiao, C.; Zhou, Y., 2020. Increased contribution of root exudates to soil carbon input during grassland degradation. Soil Biology and Biochemistry, v. 146, 107817. https://doi.org/10.1016/j.soilbio.2020.107817.

Silva, B.O.; Moitinho, M.R.; Santos, G.A.A.; Teixeira, D.D.B.; Fernandes, C.; La Scala Jr., N., 2019. Soil CO2 emission and short-term soil pore class distribution after tillage operations. Soil \& Tillage Research, v. 186, 224-232. https://doi.org/10.1016/j.still.2018.10.019.

Sisti, C.P.J.; Santos, H.P.; Kohhann, R.; Alves, B.J.R.; Urquiaga, S.; Boddey, R.M., 2004. Change in carbon and nitrogen stocks in soil under 13 years of conventional or zero tillage in southern Brazil. Soil \& Tillage Research, v. 76, (1), 39-58. https://doi.org/10.1016/j.still.2003.08.007.

Six, J.A.E.T.; Elliott, E.T.; Paustian, K., 2000. Soil macroaggregate turnover and microaggregate formation: a mechanism for $\mathrm{C}$ sequestration under no-tillage agriculture. Soil Biology and Biochemistry, v. 32, (14), 2099-2103. https://doi. org/10.1016/S0038-0717(00)00179-6.

Soil Survey Staff. 2014. Keys to Soil Taxonomy, 12th ed. USDA-Natural Resources Conservation Service, Washington, DC, 681p.

Souza, L.C.; Fernandes, C.; Moitinho, M.R.; Bicalho, E.S.; La Scala Jr., N., 2018. Soil carbon dioxide emission associated with soil porosity after sugarcane field reform. Mitigation and Adaptation Strategies for Global Change, v. 24, 113127. https://doi.org/10.1007/s11027-018-9800-5.

Tisdall, J.M.; Oades, J.M., 1982. Organic matter and water-stable aggregates in soils. Journal of Soil Science, v. 33, (2), 141-163. https://doi. org/10.1111/j.1365-2389.1982.tb01755.x.

Udom, B.E.; Omovbude, S., 2019. Soil physical properties and carbon/ nitrogen relationships in stable aggregates under legume and grass fallow. Acta Ecologica Sinica, v. 39, (1), 56-62. https://doi.org/10.1016/j.chnaes.2018.05.008

Vasques, I.C.; Souza, A.A.; Morais, E.G.; Benevenute, P.A.; Silva, L.D.C.; Homem, B.G.; Casagrande, D.R.; Silva, B.M., 2019. Improved management increases carrying capacity of Brazilian pastures. Agriculture, Ecosystems \& Environment, v. 282, 30-39. https://doi.org/10.1016/j.agee.2019.05.017.

Velasquez, E.; Lavelle, P., 2019. Soil macrofauna as an indicator for evaluating soil based ecosystem services in agricultural landscapes. Acta Oecologica, v. 100, 103446. https://doi.org/10.1016/j.actao.2019.103446.

Yeomans, J.C.; Bremner, J.M., 1988. A rapid and precise method for routine determination of organic carbon in soil. Soil Science, v. 19, (13), 1467-1476. https://doi.org/10.1080/00103628809368027. 